\title{
Observations on interactions between fluorescein- iso-thiocyanate conjugates and cells in vitro
}

\author{
G. SANDER ${ }^{1}$ AND J. P. JACOBS \\ From the National Institute for Medical Research (Hampstead Laboratories), London
}

SYNOPSIS During the course of some routine immunofluorescence studies 'non-specific' staining occurred in the absence of free fluorescein and of any known impurities. The cause of such staining seems to be associated with phasic changes occurring at varying population doublings ('passages') in species-homologous cells subjected to serial cultivation.

It has been the experience of many workers who have conducted immunofluorescent studies that there are several factors which may give rise to 'non-specific' staining, eg, the presence of free fluorescein or the instability of conjugates due to inadequately prepared or improperly stored or applied conjugates of fluorescein-iso-thiocyanate (FITC). This study was designed to investigate the immunological behaviour of cells in serial passage.

In a previous communication by Sander, Hayhoe, and McShane (1970) results of a means of detecting antibodies by immunofluorescent techniques were obtained from the study of monkey-kidney cells at a single passage infected with poliovirus at varying times from one to 24 hours. On this occasion we report on studies of thoroughly characterized stable human diploid fibroblasts which readily undergo serial propagation and thus provide a system which could be used to study possible changes occurring in a virtually confluent culture at different population doublings.

\section{Materials and Methods}

SERA

These were normal human sera from three adults, two of whom were males, and antiviral sera as indicated in Table $\mathrm{I}$.

CELLS

Human lung fibroblasts were derived (a) from a normal male foetus designated MRC-5 (Jacobs, Jones, and Baille. 1970) and (b) from a normal female

'Present address: The Mathilda \& Terence Kennedy Institute of Rheumatology, Bute Gardens, Hammersmith, London, W6 7DW Received for publication 11 October 1971. foetus designated WI-38 (Hayflick and Moorhead, 1961).

CONJUGATE

This was fluorescein-iso-thiocyanate antihuman (horse) serum and antirabbit (sheep) as shown in the Table.

VIRUSES

Poliovirus type 3 (Sabin), Semliki Forest virus, and vaccinia virus were used.

\section{MEDIUM}

Cells were propagated in Eagle's basal medium to which had been added $10 \%$ calf serum, $200 \mathrm{u} / \mathrm{ml}$ penicillin, and $100 \mu \mathrm{g} / \mathrm{ml}$ streptomycin.

The cells were propagated serially on $13 \mathrm{~mm}$ diameter coverslips and were tested periodically during their active stage of growth at population doublings within the range 17 to 30 . On the third day following subcultivation cells had multiplied to the stage where they formed a confluent monolayer on each coverslip, by which time each culture contained about $2 \times 10^{5}$ cells. At each passage all cells were treated in an identical manner.

The methods employed were as described in a previous communication by Sander (1969) and Sander et al (1970). The conjugates were tested repeatedly for any inherent defects and the procedure was standardized in such a way that any changes detected during the investigations were attributable to the occurrence of cellular variations.

\section{Results and Conclusions}

The reactions observed during the studies are shown in the Table. 


\begin{tabular}{|c|c|c|c|c|c|c|c|c|c|c|c|c|c|c|c|c|}
\hline \multirow[t]{2}{*}{ Cells } & & \multicolumn{14}{|c|}{ Cell Passage } & \multirow[t]{2}{*}{ Comment } \\
\hline & & 17 & 18 & 19 & 20 & 21 & 22 & 23 & 24 & 25 & 26 & 27 & 28 & 29 & 30 & \\
\hline WI-38 & $\begin{array}{l}1 \\
2 \\
3\end{array}$ & $\begin{array}{l}- \\
\overline{+}\end{array}$ & $\begin{array}{l}- \\
- \\
-\end{array}$ & $\begin{array}{l}- \\
(+) \\
-\end{array}$ & $\begin{array}{l}- \\
+\end{array}$ & $\begin{array}{l}+(+) \\
+(+) \\
(+)\end{array}$ & $\begin{array}{l}- \\
-\end{array}$ & $\begin{array}{l}(+) \\
- \\
-\end{array}$ & $\begin{array}{l}+ \\
(+) \\
(+)\end{array}$ & $\begin{array}{l}- \\
(+) \\
+\end{array}$ & $\begin{array}{l}++ \\
- \\
-\end{array}$ & $\begin{array}{l}++(+) \\
++(+) \\
+(+)\end{array}$ & $\begin{array}{l}+ \\
- \\
-\end{array}$ & $\begin{array}{l}++ \\
\frac{1}{i}+\end{array}$ & $\begin{array}{l}- \\
\overline{+}+\end{array}$ & $\begin{array}{l}\text { WI-38 cells-day } 3 \text { FITC conjugate } \\
\text { antihuman (horse) }\end{array}$ \\
\hline MRC 5 & $\begin{array}{l}1 \\
2 \\
3\end{array}$ & $\begin{array}{l}(\div) \\
(+)\end{array}$ & $\begin{array}{l}- \\
- \\
-\end{array}$ & $\begin{array}{l}(+) \\
(+)\end{array}$ & $\begin{array}{l}- \\
(+) \\
(+)\end{array}$ & $\begin{array}{l}- \\
-\end{array}$ & $\begin{array}{l}- \\
(+) \\
+\end{array}$ & $\begin{array}{l}(+) \\
- \\
-\end{array}$ & $\begin{array}{l}- \\
+ \\
+\end{array}$ & $\begin{array}{l}(+) \\
- \\
-\end{array}$ & $\begin{array}{l}(+) \\
(+) \\
-\end{array}$ & $\begin{array}{l}- \\
- \\
-\end{array}$ & $\begin{array}{l}+ \\
- \\
-\end{array}$ & $\begin{array}{l}- \\
-\end{array}$ & $\begin{array}{l}- \\
-\end{array}$ & $\begin{array}{l}\text { MRC-5 cells -day } 3 \text { FITC cop } \\
\text { jugate antihuman (horse) }\end{array}$ \\
\hline MRC 5 & $\begin{array}{l}1 \\
2 \\
3\end{array}$ & $\begin{array}{l}- \\
-\end{array}$ & $\begin{array}{l}- \\
-\end{array}$ & $\begin{array}{l}- \\
- \\
(+)\end{array}$ & $\begin{array}{l}+ \\
+ \\
+(+)\end{array}$ & $\begin{array}{l}- \\
-\end{array}$ & $\begin{array}{l}- \\
(+) \\
(+)\end{array}$ & $\begin{array}{l}+ \\
- \\
(+)\end{array}$ & $\begin{array}{l}(+) \\
(+) \\
(+)\end{array}$ & $\begin{array}{l}- \\
-\end{array}$ & $\begin{array}{l}(+) \\
+\end{array}$ & $\begin{array}{l}- \\
-\end{array}$ & $\begin{array}{l}- \\
-\end{array}$ & $\begin{array}{l}- \\
-\end{array}$ & $\frac{+}{i}$ & $\begin{array}{l}\text { MRC } 5 \text { cells-Day } 3 \text { FITC cons } \\
\text { jugate antihuman (horse) } \\
\text { MRC } 5 \text { cells, viral inoculation daco }\end{array}$ \\
\hline & $\begin{array}{l}\mathbf{P} \\
\mathbf{S} \\
\mathbf{V}\end{array}$ & $\begin{array}{l}+ \\
(+) \\
(+)\end{array}$ & $\begin{array}{l}(+) \\
+ \\
+\end{array}$ & $\begin{array}{l}- \\
+(+) \\
+\end{array}$ & $\begin{array}{l}+(+) \\
+(+) \\
++\end{array}$ & $\begin{array}{l}- \\
-\end{array}$ & $\begin{array}{l}(+) \\
(+) \\
(+)\end{array}$ & $\begin{array}{l}- \\
(+) \\
(+)\end{array}$ & $\begin{array}{l}+ \\
+ \\
++\end{array}$ & $\begin{array}{l}+ \\
(+) \\
+\end{array}$ & $\begin{array}{l}+ \\
+ \\
++\end{array}$ & $\begin{array}{l}- \\
(+)\end{array}$ & $\begin{array}{l}- \\
- \\
\div\end{array}$ & $\overline{-}$ & $\begin{array}{l}(+) \\
(+) \\
+(+)\end{array}$ & $\begin{array}{l}\text { 3. Polio virus type } 3,10^{5} \text { particle } \\
\text { ml-3 hr incubation. Human ant } \\
\text { serum, FITC conjugate = ants } \\
\text { human, Semliki Forest virus, } \\
\text { particles/ml. } 4 \frac{1}{2} \text { hr incubation. } \\
\text { Rabbit antiserum, FITC conjugate } \\
=\text { antirabbit. }\end{array}$ \\
\hline Cell passage & & 17 & 18 & 19 & 20 & 21 & 22 & 23 & 24 & 25 & 26 & 27 & 28 & 29 & 30 & $\begin{array}{l}\text { Vaccinia virus, } 10^{5} \text { particles } / \mathrm{ml} 20 \text { b5 } \\
\text { incubation. Rabbit antiserum, FITS } \\
\text { conjugate }=\text { antirabbit. }\end{array}$ \\
\hline
\end{tabular}

Table Reactions observed between cells and sera and between cells, sera, and viruses

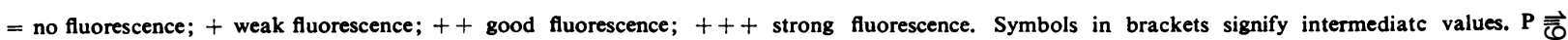
polio virus; $\mathbf{S}=$ Simliki Forest virus: $\mathrm{V}=$ vaccinia virus.

From the results the following conclusions can be drawn. (1) The binding reaction fluctuated during the period of cell cultivation and seemed to be maximal from 'passages' 24 to 30 . This pattern was similar for all three sera. (2) Where viruses were used, reactivity peaks were highest in the case of vaccinia virus.

In relation to these observations, it is important to note that in the indirect fluorescent-antibody test observed reactions may not necessarily be indicative of immunological activity, and that when attempts are being made to detect viruses by means of this method it should be borne in mind that the antiserum used may give a false positive reaction.

Where reactivity has been shown to be maximal it suggests one or more of the following possibilities: the presence of larger quantities of antigen-like material in the cell population at certain stages during their propagation; the ability of the cells to bind 'antibody' more readily at certain times; and an increase in the specificity of the antigen-like material without a concomitant increase in the quantity of this material.
The observation that where viruses were used more viral material was detected at times when maximum reactions occurred between the antiserum and the cells suggests either that the cells are at these stages more readily infected by virus, or that they are in a state which more readily allows for the synthesis of viral nucleic acid, or both. This change would seem to apply whether the agent is an RNA or a DNA virus.

We wish to record our thanks to Mr J. P. V. Hayhoe and Mrs Anne McShane for their technical assistance.

\section{References}

Jacobs, J. P., Jones, C. M., and Baille, J. P. (1970). Characteristics of a human diploid cell designated MRC-5. Nature (Lond.), 227, 168-170

Hayflick, L., and Moorhead, P. S. (1961). The serial cultivation of human diploid cell strains. Exp. Cell Res., 25, 585-621.

Sander, G. (1969). Storage of virus-infected tissue culture substrates for the detection of serum antibodies by immunofluorescence. J. clin. Path., 22, 737.

Sander, G., Hayhoe, J. P. V., and McShane, A. (1970). The preparation of virus-infected cells for use in immunofluorescence techniques. J. clin. Path., 23, 319-322. 